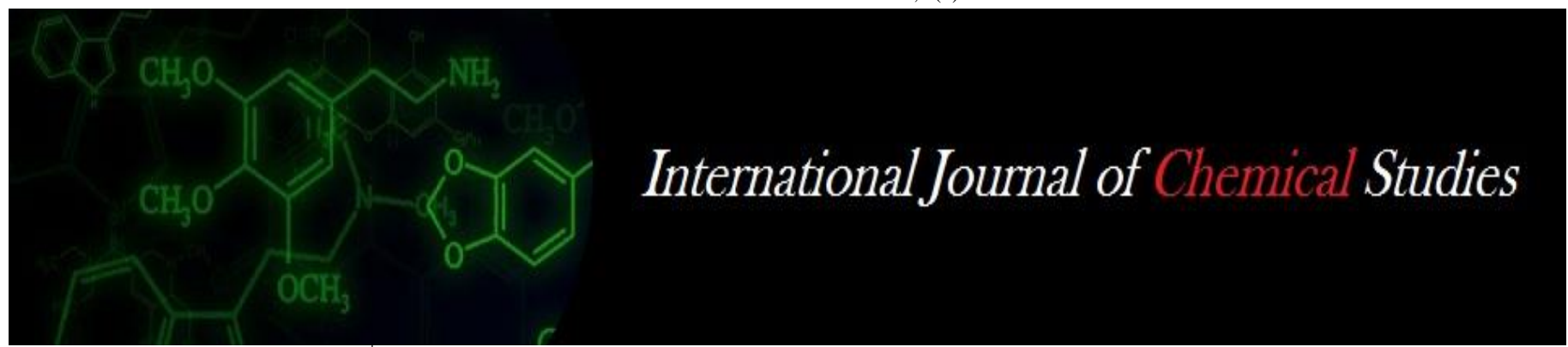

P-ISSN: 2349-8528

E-ISSN: 2321-4902

www.chemijournal.com

IJCS 2020; 8(4): 3985-3990

(C) 2020 IJCS

Received: 05-06-2020

Accepted: 10-07-2020

\section{Jaipal Jaipal}

Deptt. of Horticulture, College of Agriculture, CCS HAU, Hisar,

Haryana, India

\section{RPS Dalal}

Deptt. of Horticulture, college of

Agriculture, CCS HAU, Hisar,

Haryana, India

\section{Dinesh Kumar}

Deptt. of Horticulture, college of Agriculture, CCS HAU, Hisar,

Haryana, India

\section{Anita Kumari}

College of Basic Science \&

Humanities, Deptt. of Botany \&

Plant Physiology, CCS HAU,

Hisar, Haryana, India

\section{Reetika}

Deptt. of Horticulture, college of Agriculture, CCS HAU, Hisar,

Haryana, India
Corresponding Author:

Jaipal Jaipal

Deptt. of Horticulture, College of Agriculture, CCS HAU, Hisar,

Haryana, India

\section{Effect of rootstocks and grafting time on graft success and growth of peach cv. Shan-i-Punjab in sub tropics of India}

\author{
Jaipal Jaipal, RPS Dalal, Dinesh Kumar, Anita Kumari and Reetika
}

DOI: https://doi.org/10.22271/chemi.2020.v8.i4ay.10270

\begin{abstract}
The present investigation was carried with the aim to study the effect of time of grafting and rootstock on graft success and growth in low chill peach cv. Shan- e-Punjab under sub tropics of Haryana (India). Study comprising of three different rootstocks viz., Peach cv. Sharbati seedling and Japanese Plum cv. Kala Amritsari and European plum cv. Green Gage rooted cuttings grafted on $9^{\text {th }}$ and $25^{\text {th }}$ January with three replications. Results reveal that advanced grafting ( $9^{\text {th }}$ January) had significantly higher graft success $(64.75 \%)$ and sprouting $(69.02 \%)$ over $25^{\text {th }}$ January, whereas, all growth parameters viz., plant height, percent increase in scion diameter, fresh and dry weight of shoot and root, relative water content, leaf nitrogen and total chlorophyll contents were significantly superior when wedge grafting was done on $25^{\text {th }}$ January. On the other hand, among different rootstock, Sharbati seedling as rootstock performed better as compared to Kala Amritsari and Green Gage cutting for all the above recorded parameters. This investigation additionally gives the chances for further research to explore whether this pattern proceeds in the productive year of the peach plant.
\end{abstract}

Keywords: European plum, grafting time, Japanese plum, peach, rootstocks

\section{Introduction}

Peach (Prunus persica (L.) Batsch) belongs to the Rosaceae family, is the third most important fruit crop of temperate zones in India just as the world after apple and pear. In India, high chilling peach cultivars are predominantly cultivated in the mid hill zone at a height of 1000$2000 \mathrm{~m}$ above mean sea level. For the commercial cultivation in subtropical regions of the country, low chilling and early ripening cultivars have been suggested. The area under peach cultivation is 19 thousand hectares with 114 thousand Metric Tons production in India (Saxena, 2018) ${ }^{[11]}$. Haryana state has 322 hectares area with 3038 Metric Tons production under peach (Anonymous, 2017) ${ }^{[1]}$. Peach is a delicate, juicy and fleshy stone fruit of phenomenal appearance and quality with rich source of different sugar, vitamins and minerals. With the advancement of breeding endeavours, low chilling peach cultivars have been developed and their cultivation extends from temperate regions to subtropical areas (Küden et al., 2004) ${ }^{[7]}$. There has been remarked increment in extent of peach cultivation in north western plains of India because of effective procurement of low chilling peach cultivars, high crop economic returns and inadequacy of local fresh fruit throughout the summer season. The sub-tropical climate of Haryana suits best for the profitable low chilling peaches; therefore an incredible attention of peaches along with high quality planting material is expanding among the farmers of this area (Gangwar et al., 2003) ${ }^{[4]}$. To manage this expanding demand, efforts ought to be made for large scale, rapid and true to type multiplication of healthy planting material of suitable cultivar. In Haryana, early maturing peach cultivar like Shan-i-Punjab is favoured because of the deficiency of water accessibility during summers and more infestation of fruit fly in late maturing cultivars like Sharbati. Peaches are extremely sensitive to root rot, salt affected soils, and water logged conditions as well as there is the issue of lodging and short life. To get rid of these issues, peaches are budded onto various rootstocks, which are significant for acquiring high yield and good quality fruits as stionic interaction is responsible for water relations, gaseous exchange, nutrient uptake, tree size, blossoming period, fruit set, fruit quality and yield efficiency (Goncalves et al., 2003) ${ }^{[5]}$. Currently, peach is raised chiefly through hammer cutting and once in a while through grafting on peach rootstock, which 
further exaggerate the issues. Though, reasonable rootstock has not been standardised for commercial propagation in existing agro climatic conditions. The physiological information regarding root to shoot signalling, transfer of metabolites through vascular tissue to execute and facilitate growth and development between rootstock and scion and their interaction is essential. Consequently, standardization of suitable rootstock and time of propagation is utmost significant for maximum graft success to meet the prerequisite of plants with low cost for a specific region. However, such information about the impact of rootstock and time of propagation on scion physiology and root morphology of grafted plants are deficient in case of peach under sub-tropical zones of India. Therefore, the current investigation focussed and attended to consider the impact of rootstock on scion physiology which is the need of great importance for better growth and commercialization of peach plantation particularly under nursery stage and to standardize the time of grafting in peach to fortify peach production system under semi-arid irrigated ecosystem of Haryana.

\section{Materials and Methods}

The current study was carried out at the nursery block of department of Horticulture, CCS HAU, Hisar during the year 2018-19 to assess the impact of grafting time on different rootstock to evaluate graft success and growth in low chill peach cv. Shan- i-Punjab. The experimental orchard situated at $215.2 \mathrm{~m}$ above mean sea level with coordinates of $29^{\circ} 10^{\prime} \mathrm{N}$ latitude and $75^{\circ} 46^{\prime} \mathrm{E}$ longitudes, has a typical semi-arid climate with hot and dry summer and incredibly chilly winter. The total amount of precipitation along with its dispersion in the region is subjected to large variations. The investigational treatment entailing of two grafting times viz., 9th and 25th of January and three rootstocks viz. Peach seedling cultivar Sharbati; Japanese plum (Prunus salicina) cv. Kala Amritsari cuttings and European plum (Prunus domestica) cv. Green Gage cuttings. There were six treatment combinations arranged in randomized block design with three replications. Fifteen plants were taken for observations from each replication. One year old Sharbati seedlings and cuttings of European and Japanese plum were grafted on 9th and 25th of January. Nine year old healthy, disease free peach cv. Shan-iPunjab tree was selected for collection of the scion wood.

The grafted plants were examined for gathering the data on several parameters. The date of bud sprouting of all grafted plants was recorded on alternate days up to the completion of the sprouting and the number of days taken to first and complete sprouting from date of grafting was calculated for both grafting time and rootstock. The number of grafts sprouted and the number of successful/ survived grafts out of the total number of grafted plants was counted for each replication and expressed in percentage for sprouting and graft success, separately. The plant height was recorded from level of ground level to the peak with the assistance of the meter scale. Scion diameter was noted $5 \mathrm{~cm}$ above graft union with the assistance of Vernier caliper at the time of grafting and 150 days after grafting and expressed in percent increase in scion diameter over initial diameter. Dry weight of root and shoot was estimated by oven drying for a few days at $48{ }^{\circ} \mathrm{C}$ till consistent weight separately and ratio was worked out. Relative water content (RWC) of leaves was determined by utilizing the formula: RWC $(\%)=(\mathrm{FW}-\mathrm{DW} / \mathrm{TW}-\mathrm{DW}) \mathrm{X}$ 100 , where $\mathrm{FW}=$ Fresh weight $\mathrm{DW}=$ Dry weight, which was estimated by oven drying at $48{ }^{\circ} \mathrm{C}$ for $3-4$ days and $\mathrm{TW}=$ Turgid weight of leaves, which was resolved with the assistance of electronic balance by dipping of leaves, selected for fresh weight in distilled water for 24 hours. Total chlorophyll content of leaves was assessed according to the method of Hiscox and Israelstam (1979) ${ }^{[6]}$ utilizing dimethyl sulfoxide (DMSO). For leaf nitrogen content analysis, completely mature leaves were gathered, washed, dried, grinded and digested in diacid mixture $\left(\mathrm{H}_{2} \mathrm{SO}_{4}\right.$ and $\mathrm{HClO}_{4}$ in the ratio of 4:2) and further determined by utilizing Nessler's reagent method. The information for the above parameters was gathered at 150 days after grafting. The recorded information was compiled and subjected to statistical analysis by using OPSTAT software (Sheoran, 1998) ${ }^{[13]}$.

\section{Results and Discussion}

Grafting time and rootstock significantly influenced the days taken for first and complete sprouting (Table 1). While comparing grafting time, significantly minimum days (26.86 and 47.85) for first and complete sprouting were taken when grafting was done on 25th January over 9th January (36.74 and 59.48) respectively, irrespective of rootstock. Earliness in first and complete sprouting on 25th January over 9th January might be due to favourable environmental condition at that time. These outcomes are as per the discoveries of Chakraborty and Singh (2011) ${ }^{[2]}$ who revealed earliness in sprouting in the peach scions grafted at different time intervals as time advanced from January to February. Among different rootstocks, days taken for first and complete sprouting were significantly lower (30.96 and 50.00) for Sharbati seedling as compared to Kala Amritsari cutting (32.50 and 56.00) and Green Gage cutting (31.94 and 55.00) respectively, which were otherwise at par with each other, irrespective of grafting time. The earliest sprouting on Sharbati seedling may be possible due to earliest cambial contact of rootstock and scion of same species, resulting in quick healing and early sprouting. The interaction between grafting time and rootstock was found non-significant. The number of days taken for first and complete sprouting, respectively were minimum (26.37 and 46.00) when Sharbati seedling was grafted on 25th January, whereas the maximum days (37.56 and 62.89) were taken when Kala Amritsari cutting was grafted on 9th January, which were otherwise at par (37.11 and 61.56) with Green Gage cutting grafted on 9th January.

Table 1: Effect of rootstock and grafting time on sprouting of peach cv. Shan-i-Punjab.

\begin{tabular}{|c|c|c|c|c|c|c|}
\hline \multirow{2}{*}{ Rootstock } & \multicolumn{3}{|c|}{ Grafting time } \\
\cline { 2 - 7 } & \multicolumn{2}{|c|}{$\mathbf{9}^{\text {th }}$ Jan } & \multicolumn{2}{c|}{$\mathbf{2 5}^{\text {th }}$ Jan } & \multicolumn{2}{c|}{ Mean } \\
\cline { 2 - 7 } & $\begin{array}{c}\text { Days taken to } \\
\mathbf{1}^{\text {st }} \text { sprouting }\end{array}$ & $\begin{array}{c}\text { Days taken to } \\
\text { complete sprouting }\end{array}$ & $\begin{array}{c}\text { Days taken to } \\
\mathbf{1}^{\text {st }} \text { sprouting }\end{array}$ & $\begin{array}{c}\text { Days taken to } \\
\text { complete sprouting }\end{array}$ & $\begin{array}{c}\text { Days taken to } \\
\mathbf{1}^{\text {st }} \text { sprouting }\end{array}$ & $\begin{array}{c}\text { Days taken to } \\
\text { complete sprouting }\end{array}$ \\
\hline Peach seedling cv Sharbati & 35.59 & 54.00 & 26.37 & 46.00 & 30.96 & 50.00 \\
\hline $\begin{array}{c}\text { European plum cv. Green Gage } \\
\text { Japanese plum cv. Kala } \\
\text { Amritsari }\end{array}$ & 37.11 & 61.56 & 26.78 & 48.44 & 31.94 & 55.00 \\
\hline Mean & 37.56 & 62.89 & 27.44 & 49.11 & 32.50 & 56.00 \\
\hline
\end{tabular}


Grafting Time:

Rootstock:

Time x rootstock:

\begin{tabular}{l|l}
1.00 & 1.29 \\
1.22 & 1.57 \\
$\mathrm{NS}$ & 2.23
\end{tabular}

Sprouting (\%) was significantly affected by grafting time and rootstock (Table 2). Sprouting percentage was significantly higher $(68.02 \%)$ in plants grafted on 9th January over those plants which were grafted on 25th January $(62.91 \%)$ irrespective of rootstock. The maximum sprouting observed in Sharbati seedling $(69.02 \%)$ which was significantly higher to Kala Amritsari cutting (63.88\%) and Green Gage cutting $(63.19 \%)$ which were at par with each other irrespective of grafting time. The interaction between grafting time and rootstock was found significant. The maximum sprouting $(75.38 \%)$ was observed when Sharbati seedling were grafted on 9th January whereas the minimum sprouting $(60.33 \%)$ was recorded when Green Gage cutting were grafted on 25th January followed by Kala Amritsari cutting grafted on 9th January $(62.62 \%)$.

Table 2: Effect of rootstock and grafting time on graft success of peach cv. Shan-i-Punjab

\begin{tabular}{|c|c|c|c|c|c|c|}
\hline \multirow{3}{*}{ Rootstock } & \multicolumn{6}{|c|}{ Grafting time } \\
\hline & \multicolumn{2}{|c|}{$9^{\text {th }}$ Jan } & \multicolumn{2}{|c|}{$25^{\text {th }}$ Jan } & \multicolumn{2}{|r|}{ Mean } \\
\hline & Sprouting (\%) & Graft success (\%) & Sprouting (\%) & Graft success (\%) & Sprouting (\%) & Graft success (\%) \\
\hline Peach seedling cv Sharbati & $\begin{array}{c}93.22 \\
(75.38)\end{array}$ & $\begin{array}{c}86.44 \\
(68.52)\end{array}$ & $\begin{array}{c}79.67 \\
(63.28)\end{array}$ & $\begin{array}{c}76.39 \\
(60.98)\end{array}$ & $\begin{array}{c}86.44 \\
(69.02)\end{array}$ & $\begin{array}{c}81.42 \\
(64.75)\end{array}$ \\
\hline European plum cv. Green Gage & $\begin{array}{c}82.61 \\
(66.06)\end{array}$ & $\begin{array}{c}71.35 \\
(57.70)\end{array}$ & $\begin{array}{c}74.81 \\
(60.33)\end{array}$ & $\begin{array}{c}70.32 \\
(57.08)\end{array}$ & $\begin{array}{l}78.71 \\
(63.19)\end{array}$ & $\begin{array}{c}70.83 \\
(57.39)\end{array}$ \\
\hline Japanese plum cv. Kala Amritsari & $\begin{array}{c}78.63 \\
(62.62)\end{array}$ & $\begin{array}{c}69.76 \\
(56.72)\end{array}$ & $\begin{array}{c}81.96 \\
(65.14)\end{array}$ & $\begin{array}{c}69.61 \\
(56.65)\end{array}$ & $\begin{array}{c}80.30 \\
(63.88)\end{array}$ & $\begin{array}{c}69.69 \\
(56.65)\end{array}$ \\
\hline Mean & $\begin{array}{c}84.82 \\
(68.02)\end{array}$ & $\begin{array}{l}75.85 \\
(60.98)\end{array}$ & $\begin{array}{c}78.81 \\
(62.91)\end{array}$ & $\begin{array}{c}72.11 \\
(58.24)\end{array}$ & & \\
\hline $\mathrm{CD}$ at $5 \%$ & & $\begin{array}{r}\text { Graftin } \\
\text { Root } \\
\text { Time } \mathrm{x} r\end{array}$ & $\begin{array}{l}\text { g Time: } \\
\text { stock: } \\
\text { ootstock: }\end{array}$ & & $\begin{array}{l}2.80 \\
1.22 \\
\text { NS }\end{array}$ & $\begin{array}{l}1.61 \\
1.98 \\
2.80\end{array}$ \\
\hline
\end{tabular}

*Values in brackets are angular transformed values

Graft success was significantly affected by both the treatments, i.e., grafting time and rootstock (Table 2). Statistically higher graft success $(60.98 \%)$ was recorded when plants were grafted on 9th January over 25th January $(58.24 \%)$, irrespective of rootstock. The decrease in graft success on 25 th January can be attributed to the low activity of growth promoters and callus proliferation which are essential for successful union. Similar to our findings, Chouksey (2016) [3] likewise revealed that guava plants grafted on 20th February had the most noteworthy graft success percent over 5th March recorded following 90 days of grafting. Similarly, rootstock differed significantly in influencing graft success and higher graft success $(64.75 \%)$ was found in Sharbati seedling as compared to Kala Amritsari cutting (56.65\%) and Green Gage cutting (57.39\%), which were further found at par with each other irrespective of grafting time. Higher graft success of Shan-i-Punjab grafted on Sharbati seedling might be due to better union and grafting compatibility among peach rootstocks and scion woods due to similar genetic makeup as compared to plum cutting. The interaction between grafting time and rootstock was found significant. The maximum graft success (68.52\%) was recorded when Sharbati seedling were grafted on 9th January whereas the minimum graft success $(56.65 \%)$ was recorded when Kala Amritsari cutting were grafted on 25th January which was at par with Kala Amritsari cutting grafted on 9th January $(56.72 \%)$.

Plants grafted on 25th January showed significantly more plant height $(91.48,113.54$ and $149.51 \mathrm{~cm})$ over plants grafted on 9th January $(85.73,107.40$ and $136.07 \mathrm{~cm})$ at all dates of observations $(90,120,150 \mathrm{DAG})$, irrespective of rootstock (Table 3). It might be due to better ecological condition available for plant height at 25th January. These outcomes are in line with Plathia et al. $(2016)^{[8]}$ who stated that as the grafting time advanced from 30th December to 15th February, plant height likewise altogether diminishes at 75, 90, 105 and 120 DAG in Shan-i-Punjab grafted on Peach seedling rootstock. Rootstocks differed significantly among each other in influencing plant height at 90, 120 and 150 DAG. For achieving maximum plant height, Sharbati seedling performed significantly better $(101.09,123.50$ and 152.39 $\mathrm{cm})$ as compared to Kala Amritsari (79.46, 97.75 and 134.48 $\mathrm{cm})$ and Green Gage cutting $(85.27,110.16 \mathrm{~cm})$ at all dates of observations (90, 120, $150 \mathrm{DAG})$, respectively, irrespective of grafting time. Higher plant height in Sharbati seedling might possibly be speculated due to better cambial contact resulting into greater uptake of water and nutrients from soil and better root development in Sharbati seedling as compared to plum cutting. Sharma and Dhillon (1981) ${ }^{[12]}$ likewise noticed that peach seedling rootstock achieved essentially more tallness than plum cutting apricot seedling. The interaction between grafting time and rootstock was found non-significant at 90 and $150 \mathrm{DAG}$ and significant at $120 \mathrm{DAG}$. The maximum plant height was recorded when Sharbati seedling were grafted on 25th January (103.76 and $157.11 \mathrm{~cm})$ at 90 and 150 DAG, respectively and on 9th January $(124.71 \mathrm{~cm})$ at 120 DAG which was at par with Sharbati seedling grafted on 25th January $(122.30 \mathrm{~cm})$, whereas the minimum plant height (77.37, 95.33and $127.34 \mathrm{~cm})$ was recorded when Kala Amritsari cutting were grafted on 9th January at all dates of observation (90, 120 and 150 DAG), respectively, among which, at $120 \mathrm{DAG}$, it was at par with Kala Amritsari cutting grafted on 25th January $(100.17 \mathrm{~cm})$. 
Table 3: Effect of rootstock and grafting time on plant height $(\mathrm{cm})$ of peach cv. Shan-i-Punjab.

\begin{tabular}{|c|c|c|c|c|c|c|c|c|c|}
\hline \multirow{3}{*}{ Rootstocks } & \multicolumn{9}{|c|}{ Grafting time } \\
\hline & \multicolumn{3}{|c|}{$9^{\text {th }}$ Jan } & \multicolumn{3}{|c|}{$25^{\text {th }}$ Jan } & \multicolumn{3}{|c|}{ Mean } \\
\hline & 90 DAG & 120 DAG & 150 DAG & 90 DAG & 120 DAG & 150 DAG & 90 DAG & 120 DAG & 150 DAG \\
\hline Peach seedling cv Sharbati & 98.41 & 124.71 & 147.67 & 103.76 & 122.30 & 157.11 & 101.09 & 123.50 & 152.39 \\
\hline European plum cv. Green Gage & 81.40 & 102.17 & 133.20 & 89.13 & 118.15 & 149.82 & 85.27 & 110.16 & 141.51 \\
\hline Japanese plum cv. Kala Amritsari & 77.37 & 95.33 & 127.34 & 81.56 & 100.17 & 141.61 & 79.46 & 97.75 & 134.48 \\
\hline Mean & 85.73 & 107.40 & 136.07 & 91.48 & 113.54 & 149.51 & 88.61 & 110.47 & 142.79 \\
\hline $\mathrm{CD}$ at $5 \%$ & & & $\begin{array}{r}\text { Graftin } \\
\text { Roo } \\
\text { Time } x\end{array}$ & $\begin{array}{l}\text { Time: } \\
\text { tock: } \\
\text { otstock: }\end{array}$ & & & $\begin{array}{r}3.80 \\
4.70 \\
\text { NS }\end{array}$ & $\begin{array}{l}5.42 \\
6.64 \\
9.39\end{array}$ & $\begin{array}{r}3.16 \\
3.87 \\
\text { NS }\end{array}$ \\
\hline
\end{tabular}

The plants grafted on 25th January (3.42 and 4.08) showed significantly more percent increase in scion diameter (Table 4) over plants grafted on 9th January (3.26 and 3.81) at 120 and $150 \mathrm{DAG}$, respectively, irrespective of rootstock, whereas at 90 DAG, grafting time was found non-significant for influencing percent increase in scion diameter. Plants grafted on 25th January have maximum percent increase (2.63) in scion diameter as compared to 9th January (2.47) irrespective of rootstock at 90 DAG. Rootstocks differed significantly among each other in influencing percent increase in scion diameter at 90, 120 and 150 DAG. Among different rootstock, Sharbati seedling $(2.79,3.46$ and 4.10$)$ had better results as compared to Kala Amritsari (2.37, 3.27 and 3.84) and Green Gage cutting (2.48, 3.29 and 3.90) for achieving maximum percent increase in scion and rootstock diameter, irrespective of grafting time. It might be possible because of better rooting system of Sharbati seedling which favoured improved translocation of nutrients and water from the soil. Rana et al. (2007) [9] additionally expressed that when peach cultivar Flordasun was proliferated on plum rootstock, it indicated the smallest trunk diameter, over peach rootstocks. The interaction between grafting time and rootstock was found significant. The maximum percent increase (4.25) in scion diameter was recorded when Sharbati seedling were grafted on 25th January whereas the minimum percent increase (3.64) in scion diameter was recorded when Kala Amritsari cutting were grafted on 9th January.

Table 4: Effect of rootstock and grafting time on increase in scion diameter (\%) of peach cv. Shan-i-Punjab.

\begin{tabular}{|c|c|c|c|c|c|c|c|c|c|}
\hline \multirow{3}{*}{ Rootstocks } & \multicolumn{9}{|c|}{ Grafting time } \\
\hline & \multicolumn{3}{|c|}{$9^{\text {th }}$ Jan } & \multicolumn{3}{|c|}{$25^{\text {th }}$ Jan } & \multicolumn{3}{|c|}{ Mean } \\
\hline & 90 DAG & 120 DAG & 150 DAG & 90 DAG & 120 DAG & 150 DAG & 90 DAG & 120 DAG & 150 DAG \\
\hline Peach seedling cv Sharbati & $\begin{array}{c}6.27 \\
(2.68)\end{array}$ & $\begin{array}{l}10.44 \\
(3.37)\end{array}$ & $\begin{array}{l}14.68 \\
(3.95)\end{array}$ & $\begin{array}{c}7.55 \\
(2.90)\end{array}$ & $\begin{array}{l}11.63 \\
(3.54)\end{array}$ & $\begin{array}{l}17.11 \\
(4.10)\end{array}$ & $\begin{array}{c}6.91 \\
(2.68)\end{array}$ & $\begin{array}{l}11.04 \\
(3.46)\end{array}$ & $\begin{array}{l}15.90 \\
(4.10)\end{array}$ \\
\hline European plum cv. Green Gage & $\begin{array}{c}5.44 \\
(2.52\end{array}$ & $\begin{array}{c}9.51 \\
(3.23)\end{array}$ & $\begin{array}{l}13.85 \\
(3.85)\end{array}$ & $\begin{array}{c}5.09 \\
(2.44)\end{array}$ & $\begin{array}{l}10.25 \\
(3.21)\end{array}$ & $\begin{array}{l}14.65 \\
(3.95)\end{array}$ & $\begin{array}{c}5.27 \\
(2.48)\end{array}$ & $\begin{array}{c}9.88 \\
(3.29)\end{array}$ & $\begin{array}{l}14.25 \\
(3.90)\end{array}$ \\
\hline Japanese plum cv. Kala Amritsari & $\begin{array}{c}3.92 \\
(2.20)\end{array}$ & $\begin{array}{c}9.14 \\
(3.17)\end{array}$ & $\begin{array}{l}12.33 \\
(3.64)\end{array}$ & $\begin{array}{c}5.77 \\
(2.55)\end{array}$ & $\begin{array}{l}10.38 \\
(3.36)\end{array}$ & $\begin{array}{l}15.32 \\
(4.03)\end{array}$ & $\begin{array}{l}4.84 \\
(2.37\end{array}$ & $\begin{array}{c}9.76 \\
(3.27)\end{array}$ & $\begin{array}{l}13.83 \\
(3.84)\end{array}$ \\
\hline Mean & $\begin{array}{c}5.21 \\
(2.47)\end{array}$ & $\begin{array}{c}9.70 \\
(3.26)\end{array}$ & $\begin{array}{l}13.62 \\
(3.81) \\
\end{array}$ & \begin{tabular}{|c|}
6.13 \\
$(2.63)$ \\
\end{tabular} & $\begin{array}{l}10.75 \\
(3.42) \\
\end{array}$ & $\begin{array}{l}15.69 \\
(4.08) \\
\end{array}$ & & & \\
\hline $\mathrm{CD}$ at $5 \%$ & & & $\begin{array}{l}\text { Graftin } \\
\text { Root } \\
\text { Time x r }\end{array}$ & $\begin{array}{l}\text { g Time: } \\
\text { tock: } \\
\text { ootstock: }\end{array}$ & & & $\begin{array}{c}\mathrm{NS} \\
0.22 \\
\mathrm{NS}\end{array}$ & $\begin{array}{r}0.11 \\
0.13 \\
\mathrm{NS} \\
\end{array}$ & $\begin{array}{l}0.04 \\
0.05 \\
0.07\end{array}$ \\
\hline
\end{tabular}

*Values in brackets are angular transformed values

All the treatments significantly influenced the shoot fresh and dry weight (Table 5). Plants grafted on 25th January had significantly higher shoot fresh and dry weight (259.89 and $175.04 \mathrm{~g}$ ) over plants grafted on 9th January (199.41 and $140.21 \mathrm{~g})$, irrespective of rootstock. Rootstock differed significantly among each other in influencing the shoot fresh and dry weight. Sharbati seedling had significantly maximum shoot fresh and dry weight (265.95 and $187.72 \mathrm{~g}$ ) and the minimum shoot fresh and dry weight (190.97 and $126.78 \mathrm{~g})$ in
Kala Amritsari rootstock, irrespective of grafting time. The interaction between grafting time and rootstock was found non- significant. The maximum shoot fresh and dry weight (286.56 and $194.00 \mathrm{~g}$ ) was recorded when Sharbati seedling grafted on 25th January which was at par with Green Gage cutting grafted on 25th January (271.11 and $188.83 \mathrm{~g}$ ), whereas, the minimum shoot fresh and dry weight (159.94 and $111.28 \mathrm{~g}$ ), respectively was recorded when Kala Amritsari cutting were grafted on 9th January.

Table 5: Effect of rootstock and grafting time on shoot fresh and dry wt (g) in peach cv. Shan-i-Punjab.

\begin{tabular}{|c|c|c|c|c|c|c|}
\hline \multirow{3}{*}{ Rootstock } & \multicolumn{6}{|c|}{ Grafting time } \\
\hline & \multicolumn{2}{|c|}{$9^{\text {th }}$ Jan } & \multicolumn{2}{|c|}{$25^{\text {th }}$ Jan } & \multicolumn{2}{|c|}{ Mean } \\
\hline & Shoot fresh wt. (g) & $\begin{array}{c}\text { Shoot dry wt. } \\
\text { (g) }\end{array}$ & $\begin{array}{c}\text { Shoot fresh wt. } \\
(\mathrm{g})\end{array}$ & $\begin{array}{c}\text { Shoot dry wt. } \\
\text { (g) }\end{array}$ & $\begin{array}{c}\text { Shoot fresh } \\
\text { wt. (g) }\end{array}$ & $\begin{array}{c}\text { Shoot dry wt. } \\
\text { (g) }\end{array}$ \\
\hline Peach seedling cv Sharbati & 245.33 & 181.44 & 286.56 & 194.00 & 265.95 & 187.72 \\
\hline European plum cv. Green Gage & 192.94 & 127.89 & 271.11 & 188.83 & 232.03 & 158.36 \\
\hline Japanese plum cv. Kala Amritsari & 159.94 & 111.28 & 222.01 & 142.27 & 190.97 & 126.78 \\
\hline Mean & 199.41 & 140.21 & 259.89 & 175.04 & & \\
\hline $\mathrm{CD}$ at $5 \%$ & & $\begin{array}{r}\text { Grafting } \\
\text { Rootsto } \\
\text { Time x roo }\end{array}$ & $\begin{array}{l}\text { Time: } \\
\text { ck: } \\
\text { tstock: }\end{array}$ & & $\begin{array}{c}20.86 \\
25.55 \\
\text { NS }\end{array}$ & $\begin{array}{r}6.90 \\
8.56 \\
12.11\end{array}$ \\
\hline
\end{tabular}


The root fresh and dry weight $(\mathrm{g})$ was significantly affected by grafting time and rootstock irrespective of each other (Table 6). Plants grafted on 25th January had significantly higher root fresh and dry weight (79.93 and $49.46 \mathrm{~g}$ ) over plants grafted on 9th January (66.74 and $40.65 \mathrm{~g}$ ), irrespective of rootstock. Sharbati seedling had significantly higher root fresh and dry weight (92.19 and $68.78 \mathrm{~g}$ ) as compared to Kala Amritsari cutting (62.75 and $30.97 \mathrm{~g}$ ) and Green Gage cutting (65.06 and $35.42 \mathrm{~g}$ ), respectively, which were otherwise at par with each other, irrespective of grafting time. These outcomes are as per the discoveries of Uniyal (2008) ${ }^{[14]}$ who stated higher fresh and dry weight of shoot and root when peach scion was budded on peach rootstock than apricot and plum rootstock. Rieger (1992) ${ }^{[10]}$ likewise expressed that seedling rootstocks had higher total root dry weight than the cutting rootstocks of peach. The interaction between grafting time and rootstock was found significant for root fresh weight whereas non-significant for root dry weight. The maximum root fresh weight (103.06 g) was recorded when Sharbati seedling were grafted on 9th January whereas the minimum root fresh weight $(48.28 \mathrm{~g})$ was recorded when Green Gage cutting were grafted on 9th January which was at par with Kala Amritsari cutting grafted on 9th January (48.89 g). The increased vegetative growth in terms of plant height, percent increase in scion diameter and so on is reflected in the fresh and dry weight of shoot and roots.

Table 6: Effect of rootstock and grafting time on root fresh and dry wt (g) in peach cv. Shan-i-Punjab.

\begin{tabular}{|c|c|c|c|c|c|c|}
\hline \multirow{3}{*}{ Rootstock } & \multicolumn{6}{|c|}{ Grafting time } \\
\hline & \multicolumn{2}{|c|}{$9^{\text {th }}$ Jan } & \multicolumn{2}{|c|}{$25^{\text {th }}$ Jan } & \multicolumn{2}{|c|}{ Mean } \\
\hline & Root fresh wt. (g) & Root dry wt. (g) & Root fresh wt. (g) & Root dry wt. (g) & Root fresh wt. (g) & Root dry wt. (g) \\
\hline Peach seedling cv Sharbati & 103.06 & 65.78 & 81.33 & 71.78 & 92.19 & 68.78 \\
\hline European plum cv. Green Gage & 48.28 & 29.56 & 81.83 & 41.28 & 65.06 & 35.42 \\
\hline Japanese plum cv. Kala Amritsari & 48.89 & 26.61 & 76.61 & 35.33 & 62.75 & 30.97 \\
\hline Mean & 66.74 & 40.65 & 79.93 & 49.46 & & \\
\hline $\mathrm{CD}$ at $5 \%$ & & $\begin{array}{r}\text { Graftin } \\
\text { Root } \\
\text { Time x r }\end{array}$ & $\begin{array}{l}\text { Time: } \\
\text { tstock: } \\
\text { rootstock: }\end{array}$ & & $\begin{array}{l}10.83 \\
13.26 \\
18.76\end{array}$ & $\begin{array}{l}6.94 \\
8.50 \\
\mathrm{NS}\end{array}$ \\
\hline
\end{tabular}

The relative water content (RWC) (\%) was found significantly higher on 25 th January $(66.80 \%$ and $68.24 \%)$ over 9th January $(64.60 \%$ and $65.26 \%)$ at all dates of observations (120 and $150 \mathrm{DAG})$, respectively, except at 90 DAG, where grafting time was found non-significant for influencing RWC, irrespective of rootstock (Table 7). Plants grafted on 25th January had more RWC $(60.15 \%)$ and plants grafted on 9th January (59.08\%) showed lower RWC at 90 DAG. Among different rootstock which differed significantly for influencing relative water content, the maximum RWC was found in Sharbati seedling $(61.62 \%, 67.68 \%$ and $69.18 \%)$ as compared to Kala Amritsari $(58.82 \%, 63.95 \%$ and $64.70 \%)$ and Green Gage cutting $(58.42 \%, 65.47 \%$ and $66.37 \%)$ at all dates of observations $(90,120,150$ DAG), respectively, which were found otherwise at par with each other, irrespective of grafting time. It might be due to better absorption of water and nutrients by Sharbati seedling having better root development which resulted in higher fresh weight of leaves and ultimately into higher relative water content. The interaction between grafting time and rootstock was found non-significant at 90 and 120 DAG, whereas, significant at 150 DAG. The maximum RWC was recorded when Sharbati seedling grafted on 9th January (61.97\%) at 90 DAG and 25th January (68.26\% and $72.06 \%)$ at 120 and 150 DAG, respectively, whereas the minimum RWC $(57.17 \%$, $62.34 \%$ and $63.41 \%$ ) was recorded when Kala Amritsari cutting were grafted on 9th January at all dates of observations $(90,120,150 \mathrm{DAG})$, respectively.

Table 7: Effect of rootstock and grafting time on relative water content (\%) in peach cv. Shan-i-Punjab

\begin{tabular}{|c|c|c|c|c|c|c|c|c|c|}
\hline \multirow{3}{*}{ Rootstocks } & \multicolumn{9}{|c|}{ Grafting time } \\
\hline & \multicolumn{3}{|c|}{$9^{\text {th }}$ Jan } & \multicolumn{3}{|c|}{$25^{\text {th }}$ Jan } & \multicolumn{3}{|c|}{ Mean } \\
\hline & 90 DAG & 120 DAG & 150 DAG & 90 DAG & 120 DAG & 150 DAG & 90 DAG & 120 DAG & 150 DAG \\
\hline Peach seedling cv Sharbati & $\begin{array}{c}77.82 \\
(61.91)\end{array}$ & $\begin{array}{c}84.74 \\
(67.12)\end{array}$ & $\begin{array}{c}83.55 \\
(66.30)\end{array}$ & $\begin{array}{c}76.75 \\
(61.27)\end{array}$ & $\begin{array}{c}86.17 \\
(68.26)\end{array}$ & $\begin{array}{c}90.20 \\
(72.06)\end{array}$ & $\begin{array}{c}77.28 \\
(61.62)\end{array}$ & $\begin{array}{c}85.46 \\
(67.68)\end{array}$ & $\begin{array}{c}86.87 \\
(69.18)\end{array}$ \\
\hline European plum cv. Green Gage & $\begin{array}{c}71.77 \\
(58.11)\end{array}$ & $\begin{array}{c}81.26 \\
(64.37)\end{array}$ & $\begin{array}{c}83.46 \\
(66.08) \\
\end{array}$ & $\begin{array}{c}72.97 \\
(58.72)\end{array}$ & $\begin{array}{c}83.96 \\
(66.57) \\
\end{array}$ & $\begin{array}{c}84.15 \\
(66.67) \\
\end{array}$ & $\begin{array}{c}72.37 \\
(58.42)\end{array}$ & $\begin{array}{c}82.61 \\
(65.47)\end{array}$ & $\begin{array}{c}83.81 \\
(66.37) \\
\end{array}$ \\
\hline Japanese plum cv. Kala Amritsari & $\begin{array}{c}70.48 \\
(57.17)\end{array}$ & $\begin{array}{c}77.95 \\
(62.34) \\
\end{array}$ & $\begin{array}{c}79.91 \\
(63.41)\end{array}$ & $\begin{array}{c}75.69 \\
(60.47) \\
\end{array}$ & $\begin{array}{c}82.32 \\
(65.56)\end{array}$ & $\begin{array}{c}83.30 \\
(66.00)\end{array}$ & $\begin{array}{c}73.09 \\
(58.82) \\
\end{array}$ & $\begin{array}{c}80.14 \\
(63.95)\end{array}$ & $\begin{array}{c}81.60 \\
(64.70) \\
\end{array}$ \\
\hline Mean & $\begin{array}{c}73.36 \\
(59.08) \\
\end{array}$ & $\begin{array}{c}81.32 \\
(64.60) \\
\end{array}$ & $\begin{array}{c}82.31 \\
(65.26) \\
\end{array}$ & $\begin{array}{c}75.14 \\
(60.15) \\
\end{array}$ & $\begin{array}{c}84.15 \\
(66.80) \\
\end{array}$ & $\begin{array}{c}85.88 \\
(68.24) \\
\end{array}$ & & & \\
\hline $\mathrm{CD}$ at $5 \%$ & & & $\begin{array}{r}\text { Graftin } \\
\text { Root } \\
\text { Time x }\end{array}$ & $\begin{array}{l}\text { Time: } \\
\text { tock: } \\
\text { otstock: }\end{array}$ & & & $\begin{array}{l}\mathrm{NS} \\
2.03 \\
\mathrm{NS}\end{array}$ & $\begin{array}{l}1.82 \\
2.23 \\
\mathrm{NS}\end{array}$ & $\begin{array}{l}1.36 \\
1.67 \\
2.36\end{array}$ \\
\hline
\end{tabular}

*Values in brackets are angular transformed values

The leaf nitrogen content was found significantly higher $(2.92 \%)$ in plants grafted on 25th January over 9th January $(2.70 \%)$, irrespective of rootstock (Table 8 ). It might be due to better rootstock growth of grafted plant on 25th January as evident from the study which was responsible for more absorption of nutrients. Rootstock differed significantly among each other in influencing leaf nitrogen content. Sharbati seedling had significantly higher leaf nitrogen $(3.01 \%)$ as compared to Kala Amritsari cutting (2.60\%) and
Green Gage cutting (2.83\%), irrespective of grafting time which might be due to better root establishment and more absorption of nutrients in case of Sharbati seedling. The interaction between grafting time and rootstock was found non-significant. The maximum leaf nitrogen content (3.12\%) was recorded when Sharbati seedling grafted on 25th January whereas the minimum leaf nitrogen content (2.51\%) was recorded when Kala Amritsari cutting were grafted on 9th January. 
Table 8: Effect of rootstock and grafting time on leaf nitrogen and chlorophyll content in peach cv. Shan-i-Punjab

\begin{tabular}{|c|c|c|c|c|c|c|}
\hline \multirow{3}{*}{ Rootstock } & \multicolumn{6}{|c|}{ Grafting time } \\
\hline & \multicolumn{2}{|c|}{$9^{\text {th }}$ Jan } & \multicolumn{2}{|c|}{$25^{\text {th }}$ Jan } & \multicolumn{2}{|r|}{ Mean } \\
\hline & Leaf N (\%) & $\begin{array}{l}\text { Chlorophyll } \\
\text { content }\end{array}$ & Leaf $N(\%)$ & $\begin{array}{c}\text { Chlorophyll } \\
\text { content }\end{array}$ & Leaf $N(\%)$ & $\begin{array}{c}\text { Chlorophyll Content } \\
\text { (mg/g fresh wt.) }\end{array}$ \\
\hline Peach seedling cv Sharbati & 2.89 & 1.20 & 3.12 & 1.54 & 3.01 & 1.37 \\
\hline European plum cv. Green Gage & 2.70 & 1.19 & 2.96 & 1.25 & 2.83 & 1.22 \\
\hline Japanese plum cv. Kala Amritsari & 2.51 & 1.10 & 2.69 & 1.04 & 2.60 & 1.07 \\
\hline Mean & 2.70 & 1.16 & 2.92 & 1.27 & & \\
\hline $\mathrm{CD}$ at $5 \%$ & & $\begin{array}{l}\text { Graftin } \\
\text { Root } \\
\text { Time x r }\end{array}$ & $\begin{array}{l}\text { Time: } \\
\text { tock: } \\
\text { otstock: }\end{array}$ & & $\begin{array}{c}0.07 \\
0.09 \\
\text { NS }\end{array}$ & $\begin{array}{l}0.10 \\
0.13 \\
0.18\end{array}$ \\
\hline
\end{tabular}

The total chlorophyll content (mg/g of fresh weight) in leaves of peach $c v$. Shan-e-Punjab was significantly higher $(1.27$ $\mathrm{mg} / \mathrm{g}$ of $\mathrm{FW}$ ) in plants grafted on 25 th January over 9th January $(1.16 \mathrm{mg} / \mathrm{g}$ of $\mathrm{FW})$, irrespective of rootstock (Table 8). Rootstock differ significantly in influencing total chlorophyll content and maximum total chlorophyll content $(1.37 \mathrm{mg} / \mathrm{g}$ of $\mathrm{FW})$ was found in Sharbati seedling and minimum $(1.07 \mathrm{mg} / \mathrm{g}$ of FW) in Kala Amritsari cutting and Green Gage cutting $(1.22 \mathrm{mg} / \mathrm{g}$ of $\mathrm{FW})$, irrespective of grafting time. Total chlorophyll content might be high due to better absorption and supply of sufficient nutrients especially nitrogen, which is essential element for the synthesis of chlorophyll in 25th January and Sharabti seedling rootstock as evident from the present study itself. The interaction between grafting time and rootstock was found significant. The maximum chlorophyll content $(1.54 \mathrm{mg} / \mathrm{g}$ of $\mathrm{FW})$ was recorded when Sharbati seedling were grafted on 25th January whereas the minimum chlorophyll content $(1.04 \mathrm{mg} / \mathrm{g}$ of fresh weight) was recorded when Kala Amritsari cutting were grafted on 25th January which was at par with Kala Amritsari cutting grafted on 9th January $(1.10 \mathrm{mg} / \mathrm{g}$ of FW).

\section{Conclusion}

It can be inferred from the present study that the maximum graft success $(6475 \%)$ and sprouting percentage (69.02) was observed when grafting was performed on 9th January, whereas, all growth parameters and relative water content; leaf $\mathrm{N}$ content; and chlorophyll content were found superior when grafting was performed on 25th January.

\section{References}

1. Anonymous. Horticulture Department Report, Government of Haryana, 2017 www.hortharyana.gov.in.

2. Chakraborty B, Singh PN. Effect of rootstock and time of grafting in low-chill peach cultivars. Progressive Horticulture. 2011; 43:281-284.

3. Chouksey S. Effect of different season and deblading on wedge grafting in guava (Psidium guajava L.) cv. lucknow-49 (Doctoral dissertation, JNKVV), 2016.

4. Gangwar D, Arora RL, Gaur GS. Compatibility behavior of plum rootstocks with Peach Scions. VII International Symposium on Temperate Zone Fruits in the Tropics and Subtropics-Part Two. 2003; 696:177-180.

5. Goncalves BA, Santos AP, Silva J, Moutinho-Pereira, Torres-Pereira JMG. Effect of pruning and plant spacing on the growth of cherry rootstocks and their influence on stem water potential of sweet cherry trees. Journal of Horticultural Science and Biotechnology. 2003; 78:667672.

6. Hiscox JD, Israelstam GF. A method for the extraction of chlorophyll from leaf tissue without maceration. Canadian Journal of Botany. 1979; 57:1332-1334.
7. Küden A, Küden AB, Türkmen O, Özgüven AI, Rehber Y, Sayginer E, Imrak B. Peach, Nectarine and Plum Growing Possibilities under subtropical conditions of Turkey and North Cyprus. Acta Horticulture. 2004; 662:119-126.

8. Plathia M, Sharma A, Wali VK, Shah RA, Gupta R. Standardization of method and time of grafting of peach cv. Shan-e-Punjab on peach seedling rootstock. Green Farming. 2016; 7:1244-1247.

9. Rana GS, Daulta BS, Rana KS. Effect of rootstocks and drip irrigation on trunk diameter of peach (Prunus persica Batsch) under high density plantation. Annals of Agriculture Research. 2007; 18(2):231-233.

10. Rieger M. Growth, gas exchange, water uptake, and drought response of seedling-and cutting propagated peach and citrus rootstocks. Journal of the American Society for Horticultural Science. 1992; 117(5):834-840.

11. Saxena M. Horticultural Statistics at a Glance, 2018. www.agricoop.nic.in

12. Sharma RC, Dhillon BS. Grafting peach in October. Indian Horticulture. 1981; 26:27.

13. Sheoran OP, Tonk DS, Kaushik LS, Hasija RC, Pannu RS. Statistical Software Package for Agricultural Research Workers. Recent Advances in information theory, Statistics \& Computer Applications by D.S. Hooda and R.C. Hasija Department of Mathematics Statistics, CCS HAU, Hisar, 1998, 139-143.

14. Uniyal D. Nursery performance of some stone fruits on various rootstocks under mid-hill agroclimatic conditions of Uttarakhand (Doctoral dissertation, GB Pant University of Agriculture and Technology, Pantnagar263145 (Uttarakhand)), 2008. 